\title{
Spectroscopic Characterization and Quantitative Estimation of Natural Weathering of Silicates in Sediments of Dikrong River, India
}

\author{
Bhaskar J. Saikia1, Satya R. Goswami ${ }^{2}$, Roshmi Borthakur ${ }^{2,3}$, Indu B. Roy ${ }^{2,3}$, Rashmi R. Borah ${ }^{3}$ \\ ${ }^{1}$ Department of Physics, Anandaram Dhekial Phookan College, Nagaon, India \\ ${ }^{2}$ Department of Physics, Assam Downtown University, Guwahati, India \\ ${ }^{3}$ Department of Physics, Nowgong College, Nagaon, India \\ Email: vaskar r@rediffmail.com
}

Received 27 July 2015; accepted 21 September 2015; published 24 September 2015

Copyright (C) 2015 by authors and Scientific Research Publishing Inc.

This work is licensed under the Creative Commons Attribution International License (CC BY).

http://creativecommons.org/licenses/by/4.0/

(c) (i) Open Access

\begin{abstract}
The sediments samples were collected from the Dikrong River at various sites to assess the weathering nature and mineral characterization. The Fourier Transform Infrared (FTIR) and X-ray fluorescence (XRF) spectroscopic techniques have been used to characterization of minerals in the sediment samples. The plagioclase index of alteration (PIA), chemical index of alteration (CIA) and index of compositional variation (ICV) are investigated for evaluating the weathering nature in the sediment. The obtained results show the presence of quartz, feldspar in different structure and kaolinite as major minerals. Carbonates and organic carbon are found as minor minerals. The correlations of $\mathrm{SiO}_{2}$ with major elements are authenticated the presence of bulk quartz grains and primary depositional environment. The presence of metamorphosed pyrophanite $\left(\mathrm{MnTiO}_{3}\right)$ in the adjoined areas is reported. The presence of infrared absorption peaks in between 1611 - 1622 $\mathrm{cm}^{-1}$ in this study is indicative to the weathered metamorphic origin of the silicate minerals. The index of compositional variation indicates the presence of less clay minerals and more rock forming minerals such as plagioclase and alkali-feldspar. The obtained results exhibit the area belongs to the intermediate silicate weathering.
\end{abstract}

\section{Keywords}

FTIR, Silicate Weathering, River Sediment 


\section{Introduction}

Weathering of rocks is one of the most important processes which modify the Earth's surface. The weathering and mineralogical studies of sediments are helpful in understanding the different sediment sources, environmental parameters influencing the weathering of source rocks, duration of weathering, transportation and post-depositional processes, element distribution pattern and evaluating the environmental conditions existing in an area. The focus on mineralogical, geochemical and geophysical studies and chemical composition of sediments of many Indian rivers were done by many authors [1]-[13]. The variations in bulk rock composition or weatherable rocks can generate significant differences in dissolved chemical components. The dissolved chemical load and sediment flux of Brahmaputra river has significantly higher rates of physical and chemical weathering than other large Himalayan catchments [14]-[20]. The total sediment budget of Brahmaputra particularly depends on the nature of weathering of the adjoin areas and erosion of its tributaries. The weathering of silicate minerals exposed on the continents is the largest sink of atmospheric $\mathrm{CO}_{2}$ on geological time scales [21]. In many weathering environment, the chemical weathering of silicate minerals results in the formation of secondary clays. As deposition occurs over time i.e. the deep sediments become a historical record of the temporal trends of chemicals in the environment. However, studies of river sediments especially big rivers and sedimentary rock geochemistry have made important contributions all over the world to interpret tectonic settings and estimates of average upper crustal composition. The heavy metal contaminations and silicate mineral distribution due to weathering of the Subansiri river sediments, one of the most important tributaries of Brahmaputra, is discussed elsewhere by Saikia et al. [22] [23]. This study is conducted to make a systematic assessment of the sediments due to weathering of Dikrong river, one of the major tributary of Subansiri River, using spectroscopic method.

\section{Experimental Methods}

The present study covers a total length of $60 \mathrm{Km}$ of Dikrong river, from which 6 locations were selected at a separation distance of $10 \mathrm{Km}$ approximately. The river basin consist of the Bomdila Group (Precambrian), the Gondwanas, the Siwaliks and the Quaternaries. The Gondwanas are thrusted over the Siwaliks along the Main Boundary Thrust (MBT). The river is flowing through the Kimin Formation of Upper Siwaliks and the Quaternaries comprising the Pleistocene and Recent deposits. In the dry season the sediment sample were hand-dug at $<5 \mathrm{~m}$ distance from the stems of Dikrong river, and sampled at a depth $100-150 \mathrm{~cm}$. Each sample has a weight of 2 - $3 \mathrm{~kg}$ approximately. Bulk sediment samples were dried at $40^{\circ} \mathrm{C}$ for $48 \mathrm{~h}$ and stored in black polythene bags. A part of the moisture removed samples are sieved to $>2 \mathrm{~mm}$. Further the sample was crushed into fine powder for analysis, by using agate mortar. The powdered sample was homogenized in spectrophotometric grade $\mathrm{KBr}(1: 20)$ in an agate mortar and was pressed with $3 \mathrm{~mm}$ pellets using a hand press. The infrared spectrum was acquired using Perkin-Elmer system 2000 FTIR spectrophotometer with helium-neon laser as the source reference, at a resolution of $4 \mathrm{~cm}^{-1}$. The spectra were taken in transmission mode in the region $400-4000$ $\mathrm{cm}^{-1}$. The room temperature was $30^{\circ} \mathrm{C}$ during the experiment. The composition of the samples were determined using a Philips MagiX PRO wavelength dispersive X-ray spectrometer with a rhodium anode X-ray tube was used, which may operated at up to $60 \mathrm{kV}$ and current up to $125 \mathrm{~mA}$, at a maximum power level of $4 \mathrm{~kW}$. The calibration and reproducibility of this apparatus is discussed elsewhere [24]. The precision and accuracy of the data is $\pm 2 \%$, and average values of three replicates were taken for each determination.

\section{Results and Discussions}

Compositions of the major oxides and elements of the samples are provided in Table 1. The observed concentration is reported as \%wt. The major oxide composed of $\mathrm{SiO}_{2}(75.44-79.11) ; \mathrm{Al}_{2} \mathrm{O}_{3}(11.61-15.01) ; \mathrm{TiO}_{2}(0.11$ - 0.34); $\mathrm{Fe}_{2} \mathrm{O}_{3}$ (1.03 - 1.18); $\mathrm{MnO}$ (0.02 - 0.06); $\mathrm{CaO}$ (0.49 - 0.96); $\mathrm{MgO}$ (0.18 - 0.37); $\mathrm{Na}_{2} \mathrm{O}$ (2.57 - 4.02$) ; \mathrm{K}_{2} \mathrm{O}$ (2.03 - 3.91) and $\mathrm{P}_{2} \mathrm{O}_{5}(0.02$ - 0.06). The loss on ignition (LOI) ranges from 0.69 to 1.97 wt\%. The observed major elements are Si (35.27 - 36.98); Al (6.14 - 7.94); Fe (0.72 - 0.83); Ca (0.35 - 0.69); Mg (0.11 - 0.22); K (1.69 - 3.25); Na (1.91 - 2.98); Ti (0.07 - 0.20); P (0.009 - 0.026) and Mn (0.02 - 0.05).

In Table 2 of correlation matrix, it is observed that $\mathrm{SiO}_{2}$ shows negative correlation with all major elements except for $\mathrm{K}_{2} \mathrm{O}$ with a weak positive correlation (0.26). The negative correlations of $\mathrm{SiO}_{2}$ with major elements is authenticated the presence of bulk quartz grains. The weak positive correlation of $\mathrm{SiO}_{2}$ with $\mathrm{K}_{2} \mathrm{O}$ indicates increase of clay content with decrease of quartz. $\mathrm{Al}_{2} \mathrm{O}_{3}$ shows moderate positive correlation with $\mathrm{CaO}(0.41)$ and 
Table 1. Major oxide and elemental compositions (wt\%) of the samples.

\begin{tabular}{|c|c|c|c|c|c|c|}
\hline \multirow{2}{*}{ Elements } & \multicolumn{6}{|c|}{ Sample } \\
\hline & S-1 & S-2 & S-3 & S-4 & S-5 & S-6 \\
\hline $\mathrm{SiO}_{2}$ & 77.28 & 78.36 & 76.64 & 79.11 & 77.43 & 75.44 \\
\hline $\mathrm{Al}_{2} \mathrm{O}_{3}$ & 13.16 & 12.26 & 15.01 & 11.61 & 12.87 & 13.64 \\
\hline $\mathrm{Fe}_{2} \mathrm{O}_{3}$ & 1.03 & 1.08 & 1.04 & 1.06 & 1.14 & 1.18 \\
\hline $\mathrm{CaO}$ & 0.71 & 0.74 & 0.67 & 0.49 & 0.53 & 0.96 \\
\hline $\mathrm{MgO}$ & 0.18 & 0.31 & 0.24 & 0.26 & 0.34 & 0.37 \\
\hline K2O & 2.43 & 2.13 & 2.03 & 3.91 & 2.89 & 3.16 \\
\hline $\mathrm{Na}_{2} \mathrm{O}$ & 3.87 & 2.84 & 3.01 & 2.57 & 3.87 & 4.02 \\
\hline $\mathrm{TiO}_{2}$ & 0.34 & 0.22 & 0.12 & 0.18 & 0.17 & 0.11 \\
\hline $\mathrm{P}_{2} \mathrm{O}_{5}$ & 0.02 & 0.03 & 0.05 & 0.03 & 0.04 & 0.06 \\
\hline $\mathrm{MnO}$ & 0.05 & 0.06 & 0.06 & 0.02 & 0.03 & 0.03 \\
\hline LOI & 0.93 & 1.97 & 1.13 & 0.76 & 0.69 & 1.03 \\
\hline $\mathrm{Si}$ & 36.13 & 36.63 & 35.83 & 36.98 & 36.2 & 35.27 \\
\hline $\mathrm{Al}$ & 6.96 & 6.49 & 7.94 & 6.14 & 6.82 & 7.22 \\
\hline $\mathrm{Fe}$ & 0.72 & 0.755 & 0.727 & 0.742 & 0.797 & 0.825 \\
\hline $\mathrm{Ca}$ & 0.507 & 0.529 & 0.479 & 0.35 & 0.379 & 0.686 \\
\hline $\mathrm{Mg}$ & 0.109 & 0.187 & 0.145 & 0.157 & 0.205 & 0.223 \\
\hline K & 2.02 & 1.77 & 1.69 & 3.25 & 2.40 & 2.62 \\
\hline $\mathrm{Na}$ & 2.87 & 2.11 & 2.23 & 1.91 & 2.87 & 2.98 \\
\hline $\mathrm{Ti}$ & 0.204 & 0.132 & 0.072 & 0.108 & 0.102 & 0.066 \\
\hline $\mathrm{P}$ & 0.009 & 0.013 & 0.022 & 0.013 & 0.018 & 0.026 \\
\hline $\mathrm{Mn}$ & 0.039 & 0.047 & 0.047 & 0.016 & 0.023 & 0.023 \\
\hline
\end{tabular}

Table 2. Pearson's correlation coefficient between different oxides of the sediment samples.

\begin{tabular}{|c|c|c|c|c|c|c|c|c|c|c|}
\hline & $\mathrm{SiO}_{2}$ & $\mathrm{Al}_{2} \mathrm{O}_{3}$ & $\mathrm{Fe}_{2} \mathrm{O}_{3}$ & $\mathrm{CaO}$ & $\mathrm{MgO}$ & $\mathrm{K}_{2} \mathrm{O}$ & $\mathrm{Na}_{2} \mathrm{O}$ & $\mathrm{TiO}_{2}$ & $\mathrm{P}_{2} \mathrm{O}_{5}$ & $\mathrm{MnO}$ \\
\hline $\mathrm{SiO}_{2}$ & 1.00 & & & & & & & & & \\
\hline $\mathrm{Al}_{2} \mathrm{O}_{3}$ & -0.78 & 1.00 & & & & & & & & \\
\hline $\mathrm{Fe}_{2} \mathrm{O}_{3}$ & -0.50 & -0.03 & 1.00 & & & & & & & \\
\hline $\mathrm{CaO}$ & -0.75 & 0.41 & 0.43 & 1.00 & & & & & & \\
\hline $\mathrm{MgO}$ & -0.30 & -0.10 & 0.93 & 0.32 & 1.00 & & & & & \\
\hline $\mathrm{K}_{2} \mathrm{O}$ & 0.26 & -0.58 & 0.33 & -0.28 & 0.26 & 1.00 & & & & \\
\hline $\mathrm{Na}_{2} \mathrm{O}$ & -0.72 & 0.33 & 0.54 & 0.47 & 0.24 & -0.07 & 1.00 & & & \\
\hline $\mathrm{TiO}_{2}$ & 0.38 & -0.35 & -0.55 & -0.15 & -0.66 & -0.21 & 0.11 & 1.00 & & \\
\hline $\mathrm{P}_{2} \mathrm{O}_{5}$ & -0.75 & 0.60 & 0.66 & 0.50 & 0.65 & 0.04 & 0.27 & -0.89 & 1.00 & \\
\hline $\mathrm{MnO}$ & -0.11 & 0.48 & -0.50 & 0.26 & -0.39 & -0.96 & -0.15 & 0.26 & -0.14 & 1.00 \\
\hline
\end{tabular}


$\mathrm{Na}_{2} \mathrm{O}(0.33)$ with moderate negative correlation with $\mathrm{K}_{2} \mathrm{O}(0.58)$. This co-variation indicates that alkali-bearing minerals have significant influence on $\mathrm{Al}$ distribution and suggests that the bulk of $\mathrm{Al}$, $\mathrm{Ca}$ and $\mathrm{Na}$ are primarily contributed by clay minerals [25]. The strong negative correlation of $\mathrm{SiO}_{2}$ with $\mathrm{CaO}(-0.75)$ and $\mathrm{Al}_{2} \mathrm{O}_{3}(-0.78)$ is indicative to the primary depositional environment of carbonates [26] and increase in clay fraction respectively. The manganese titanium oxide mineral pyrophanite $\left(\mathrm{MnTiO}_{3}\right)$ is usually found in metamorphosed manganese deposits. The positive correlation of $\mathrm{MnO}$ with $\mathrm{TiO}_{2}(0.26)$ may indicative to the presence of metamorphosed pyrophanite $\left(\mathrm{MnTiO}_{3}\right)$ deposition. The presence of pyrophanite $\left(\mathrm{MnTiO}_{3}\right)$ in the adjoin areas of the study sits has already reported by Saikia et al. [23].

In order to estimate the nature of weathering intensity in the sediments, we applied commonly used weathering indices Plagioclase Index of Alteration, Chemical Index of Alteration and Index of Compositional Variation which were proven to be well applicable to lithology [27]-[31].

Plagioclase is one of the most abundant mineral in the earth's crust and is highly vulnerable to alteration and weathering. In basaltic to andesitic rocks, the plagioclase group ranging sodium feldspar to calcium feldspar as the major constituents. The end members of their constituents demonstrate the parent environment and material. Plagioclase index of alteration (PIA) values are generally used to quantify the degree of source rock weathering [28]. The PIA can be calculated using the relation proposed by Fedo et al. (1995) [28] as:

$$
\mathrm{PIA}=\left\{\frac{\mathrm{Al}_{2} \mathrm{O}_{3}}{\left(\mathrm{Al}_{2} \mathrm{O}_{3}+\mathrm{CaO}+\mathrm{Na}_{2} \mathrm{O}\right)}\right\} \times 100
$$

The maximum PIA value is (equal to 100) indicative to completely altered material such as kaolinite, gibbsite etc. whereas the half of the maximum PIA value indicates unweathered plagioclase. The studied sample exhibits the range of PIA value from 73.25 - 80.31 with average value 76.47 which is indicative to the weathering nature of the source rocks (Table 3). The prominent plagioclase weathering is observed in the adjoin area of site S-3. The site S-6 suffers less plagioclase weathering among the study sites. The rest sites suggest almost moderate plagioclase weathering in source area.

The chemical index of alteration (CIA) is a constructive technique to evaluate the progressive alteration of plagioclase and K-feldspars to clay minerals. The study of Nesbitt and Young (1982) [27] reveals the degree of weathering can be estimated by calculation of the Chemical Index of Alteration (CIA), based on molecular proportions (i.e. mass\% of the oxide of an element divided by molar weight of the oxide) given as:

$$
\mathrm{CIA}=\left\{\frac{\mathrm{Al}_{2} \mathrm{O}_{3}}{\mathrm{Al}_{2} \mathrm{O}_{3}+\mathrm{CaO}+\mathrm{K}_{2} \mathrm{O}+\mathrm{Na}_{2} \mathrm{O}}\right\} \times 100
$$

In this relation, $\mathrm{Al}$ is considering as static and the changes in CIA reflects the changing proportions of feldspar and Al-rich secondary minerals in the depositional environment. In weathering, feldspars are dissolved by acid hydrolysis and hence their constituting cations $\mathrm{Na}, \mathrm{Mg}$, Ca, and $\mathrm{K}$ are leached [27] [28]. The more static elements such as $\mathrm{Si}$ and $\mathrm{Al}$ remain stable in the same environment and forms oxidic minerals. Therefore, low values of CIA indicate little chemical alteration while a high values infers an intensive alteration and leaching of the mobile cations relative to the residual Al during weathering [27] [28].

\begin{tabular}{ccccccc}
\multicolumn{7}{l}{ Table 3. Value of CIA, $\mathrm{PIA}, \mathrm{Al} / \mathrm{Na}, \mathrm{K} / \mathrm{Na}$ and $\mathrm{K}_{2} \mathrm{O} / \mathrm{Al}_{2} \mathrm{O}_{3}$. } \\
\hline Sample & CIA & PIA & ICV & Al/Na & $\mathrm{K} / \mathrm{Na}$ & $\mathrm{K}_{2} \mathrm{O} / \mathrm{Al}_{2} \mathrm{O}_{3}$ \\
\hline S-1 & 65.25 & 74.18 & 25.32 & 2.43 & 0.70 & 0.185 \\
S-2 & 68.22 & 77.40 & 33.55 & 3.08 & 0.84 & 0.174 \\
S-3 & 72.44 & 80.31 & 59.75 & 3.56 & 0.75 & 0.135 \\
S-4 & 62.49 & 79.14 & 47.17 & 3.22 & 1.70 & 0.337 \\
S-5 & 63.84 & 74.52 & 52.76 & 2.38 & 0.84 & 0.225 \\
S-6 & 62.63 & 73.25 & 89.36 & 2.42 & 0.88 & 0.232 \\
Average & $\mathbf{6 5 . 8 1}$ & $\mathbf{7 6 . 4 7}$ & $\mathbf{5 1 . 3 2}$ & $\mathbf{2 . 8 5}$ & $\mathbf{0 . 9 5}$ & $\mathbf{0 . 2 1 4}$ \\
\hline
\end{tabular}


Therefore CIA values of the sediments are used as an important indicator of the intensity of weathering in the provenance area. CIA values of unweathered igneous rocks and fresh feldspar ranges from 40 - 50, whereas in intensely weathered residue rocks it approaches to 100 [27]. The observed CIA value of the studied sediment samples are in between 62.48 - 72.44 with an average of 65.81 which is considered to represent low to moderate degree of weathering (Table 3). The sample site-3 has highest weathering condition whereas the sample site-6 has undergoes least weathering condition among the samples.

The composition of non-quartz components of the sample can be evaluated by calculating the Index of Compositional Variation (ICV) proposed by Cox et al., (1995) as:

$$
\mathrm{ICV}=\frac{\left(\mathrm{Fe}_{2} \mathrm{O}_{3}+\mathrm{K}_{2} \mathrm{O}+\mathrm{Na}_{2} \mathrm{O}+\mathrm{CaO}+\mathrm{MgO}+\mathrm{MnO}+\mathrm{TiO}_{2}\right)}{\mathrm{TiO}_{2}}
$$

The ICV value less than 1 indicates the presence of more clay minerals whereas its value greater than 1 indicates more rock forming minerals such as plagioclase, alkali-feldspar, pyroxenes etc. [29]. The ICV values of the samples varied from 25.32 to 89.36 with average value 51.32 (Table 3). The average ICV value indicates the presence of less clay minerals and more rock forming minerals such as plagioclase, alkali-feldspar etc. [29].

The PIA and CIA describe the weathering in source area as to weathering during long distance transportation, i.e. even if there was intensive weathering in the source area, the sediments as well may not travel far before been deposited [28] [32]. A high CIA and PIA values (ranged 75 to 100) indicative to intensive weathering in source area with residue of little amount of feldspar. The CIA and PIA values in between 60 to 70 indicates moderate weathering and their value less than 60 indicates low weathering of the source area [28]-[32]. The study samples have the average CIA and PIA values 65.81 and 76.46 respectively (Table 3). Therefore, moderate to intensive nature of weathering of the source areas may be considered.

The $\mathrm{K}_{2} \mathrm{O} / \mathrm{Al}_{2} \mathrm{O}_{3}$ ratios indicates how much of alkali feldspar versus plagioclase and clay minerals were present in the original rock. The $\mathrm{K}_{2} \mathrm{O} / \mathrm{Al}_{2} \mathrm{O}_{3}$ ratio are less than 0.3 and $0.3-0.9$ respectively for clays and feldspars. This ratio of the studied samples is ranged between 0.135 - 0.337 with average value 0.214 (Table 3). These values indicate predominance of clay minerals over alkali-bearing minerals such as K-feldspars and micas [29].

The extent of the weathering of the silicate is shown in Figure 1 in the plots of PIA, Al/Na and K/Na against chemical index of alteration (CIA). It demonstrates the varying degrees of chemical weathering as: no silicate weathering, low silicate weathering, intermediate silicate weathering and extreme silicate weathering after Nesbitt and Young (1982); Roy et al. (2008) [28]-[32]. The interrelation between both indexes reflects the silicate weathering intensity. It exhibits the studied samples belong to the intermediate silicate weathering.

The observed infrared frequencies of the studied sediment samples are comparing with the available literature of Gadsden (1976) and the minerals such as such as quartz, microcline, orthoclase, albite, kaolinite, illite, vermiculite, calcite, aragonite and organic compounds were identified [33]. The observed frequencies are interpreted in Table 4.

The mid infrared spectra of quartz in between the range $1200-400 \mathrm{~cm}^{-1}$ are classified into four characteristic bands around 1080 - 1175, 780 - 800, 695 and $450-464 \mathrm{~cm}^{-1}$ due to Si-O asymmetrical stretching vibration (v3), Si-O symmetrical stretching vibration (v1), Si-O symmetrical bending vibration (v2) and Si-O asymmetrical bending vibration (v4) respectively [34] [35]. In the observed infrared spectra of the samples (Figure 2 and Table 4), the absorption bands appearing at $458-462,512-520,693-696,777-781$ and $1080-1090 \mathrm{~cm}^{-1}$ is suggested the presence of quartz in the samples. The bands around $1000 \mathrm{~cm}^{-1}$ appears due to the silicon-oxygen stretching vibrations and the tetrahedral-tetrahedral ion vibrations affected the band around $780 \mathrm{~cm}^{-1}$ for silicate, the tetrahedral dimensions are generally considered to be little affected by pressure and temperature. The absorption band at $695 \mathrm{~cm}^{-1}$ arises due to the octahedral site symmetry. The tetrahedral site symmetry is stronger to that of octahedral site symmetry. Therefore, for any structural change, the damage occurs first in octahedral site symmetry then in tetrahedral site symmetry. The intensity of the bands due to the vibrations of these two symmetries will provide direct information on the crystallinity. It is well known that in the infrared spectra of amorphous silica the symmetrical bending vibration of the Si-O group found at $695 \mathrm{~cm}^{-1}$ is absent. Therefore, the symmetrical bending vibrations of Si-O group obtained at $695 \mathrm{~cm}^{-1}$ is diagnostic peak in determining the short range parameter of the quartz, whether it is crystalline or amorphous [36]-[39]. In the all studied samples we observed this characteristic peak at $695 \mathrm{~cm}^{-1}$. It suggests that the observed quartz in the samples were well crystalline in nature. The absorption peaks at $1615-1620 \mathrm{~cm}^{-1}$ indicates the presence of quartz in river sediments 

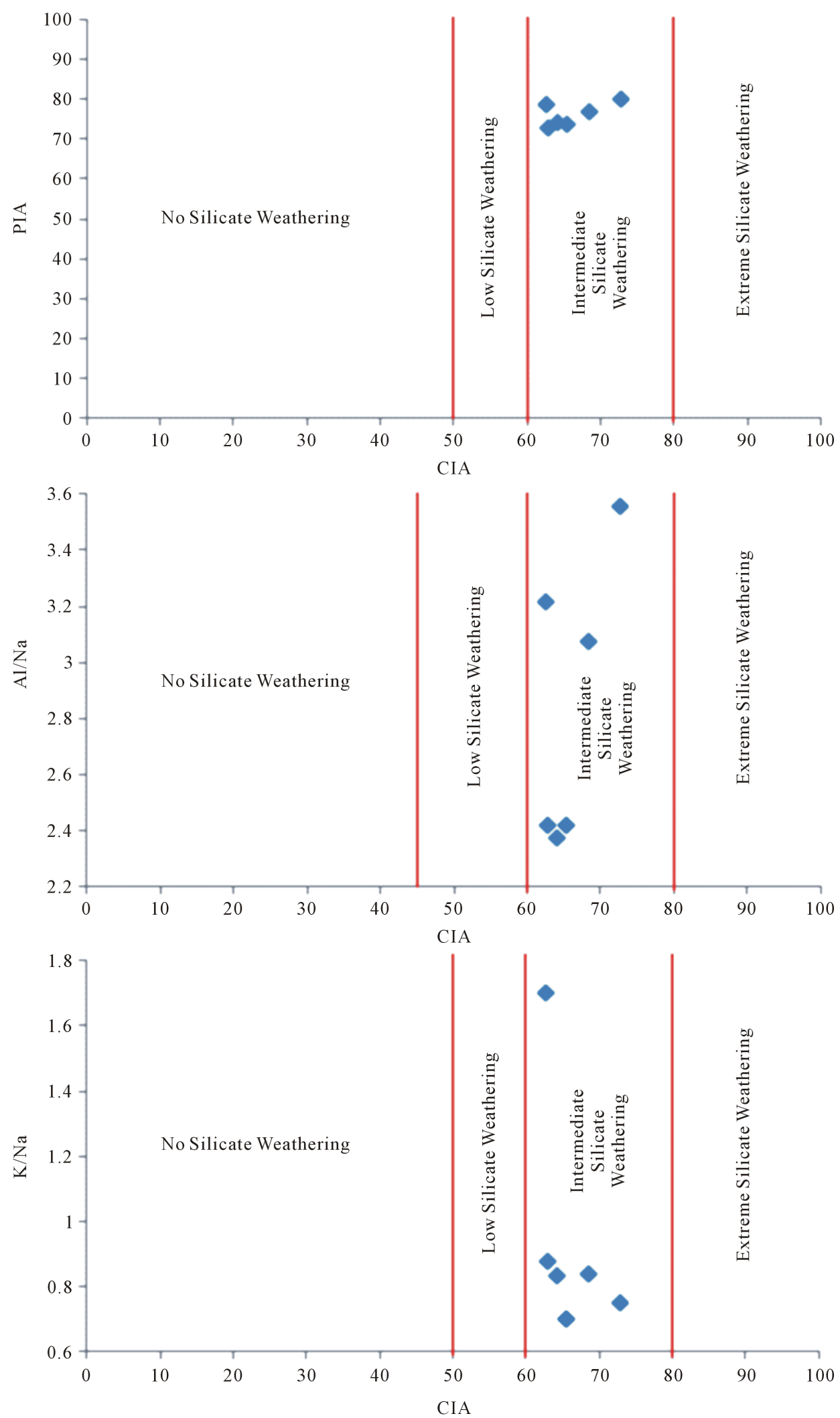

Figure 1. The plot of Plagioclase index of alteration (PIA), $\mathrm{Al} / \mathrm{Na}$ and $\mathrm{K} / \mathrm{Na}$ against Chemical index of Alternation (CIA). 


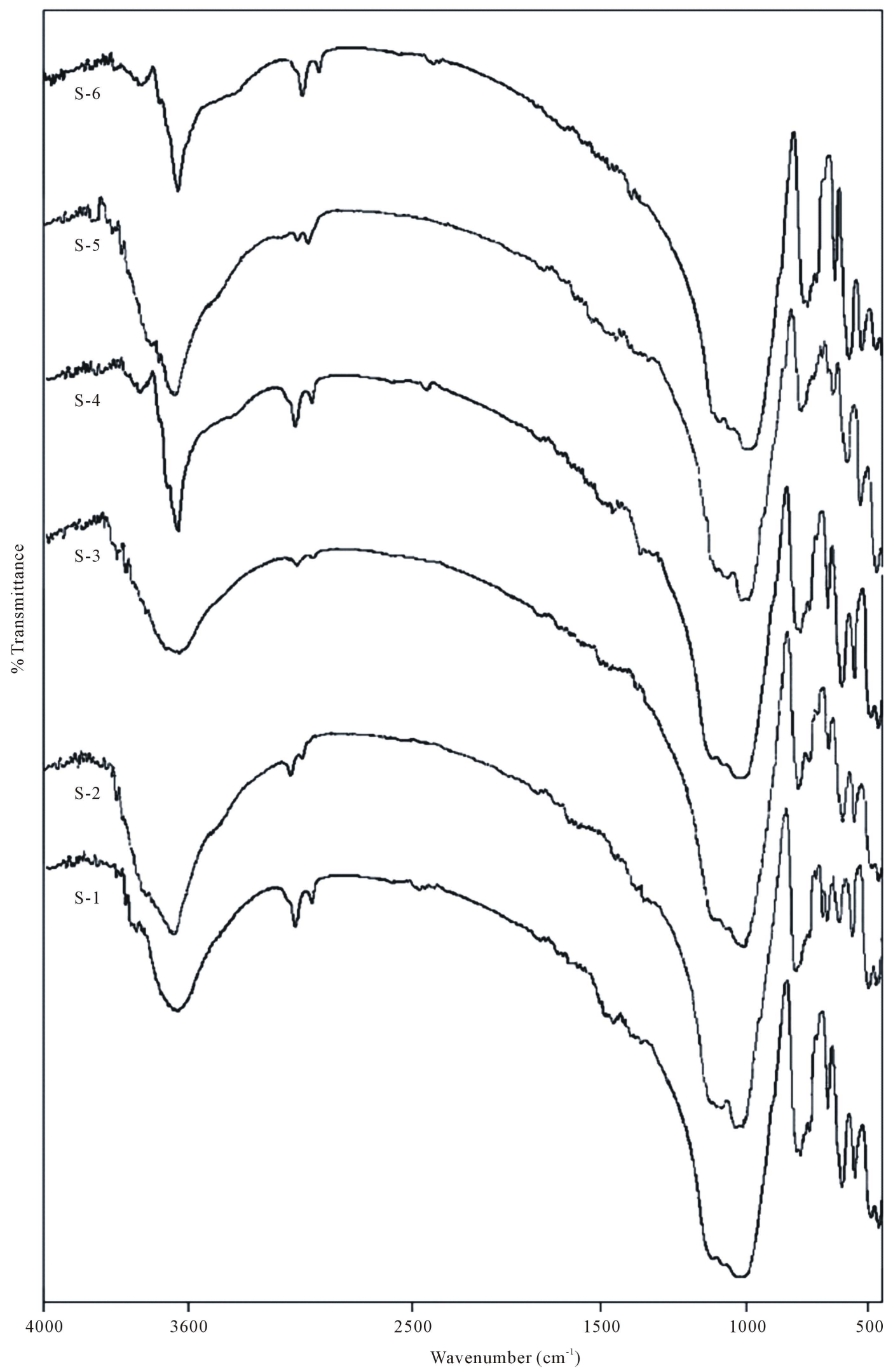

Figure 2. FTIR absorption spectra for the studied sediment samples in the range $4000-500 \mathrm{~cm}^{-1}$. 
Table 4. Observed wavenumbers $\left(\mathrm{cm}^{-1}\right)$ of infrared spectra with corresponding identified minerals.

\begin{tabular}{|c|c|c|c|c|c|c|c|c|c|}
\hline \multirow{2}{*}{ Sample } & \multirow{2}{*}{ Quartz } & \multicolumn{3}{|c|}{ Feldspar } & \multicolumn{2}{|c|}{ Clay mineral } & \multicolumn{2}{|c|}{ Carbonate mineral } & \multirow{2}{*}{$\begin{array}{c}\text { Organic } \\
\text { compound }\end{array}$} \\
\hline & & Microcline & Orthoclase & Albite & Kaolinite & Illite & Calcite & Aragonite & \\
\hline \multirow{6}{*}{ S-1 } & 462 & 427 & 430 & 649 & 475 & 871 & 1433 & 1459 & 2849 \\
\hline & 515 & 467 & 533 & 721 & 540 & & 1822 & 2519 & 2928 \\
\hline & 694 & 589 & 727 & 1002 & 1005 & & & & 2966 \\
\hline & 779 & 1049 & 1148 & 1092 & 3627 & & & & \\
\hline & 1090 & & & & 3671 & & & & \\
\hline & 1622 & & & & & & & & \\
\hline \multirow{7}{*}{ S-2 } & 459 & 587 & 534 & 421 & 477 & 926 & 1825 & 855 & 2850 \\
\hline & 520 & 1048 & 646 & 725 & 542 & 3409 & & 1508 & 2924 \\
\hline & 695 & 1325 & 765 & & 1015 & & & 1792 & \\
\hline & 781 & & 1150 & & 1118 & & & & \\
\hline & 1080 & & & & 3624 & & & & \\
\hline & & & & & 3646 & & & & \\
\hline & & & & & 3660 & & & & \\
\hline \multirow{5}{*}{ S-3 } & 460 & 427 & 532 & 721 & 539 & 3630 & 1824 & 1455 & 2852 \\
\hline & 512 & 468 & 644 & 1003 & 3672 & & & 1524 & 2922 \\
\hline & 694 & 588 & 1040 & 1095 & & & & 1792 & \\
\hline & 778 & & 1148 & & & & & & \\
\hline & 1615 & & & & & & & & \\
\hline \multirow{5}{*}{ S-4 } & 462 & 428 & 540 & 532 & 1007 & 870 & 1428 & 1796 & 2852 \\
\hline & 695 & 467 & 1151 & 645 & 3626 & 3402 & 1821 & 2515 & 2927 \\
\hline & 777 & 586 & & 722 & 3645 & & & & 2988 \\
\hline & 1619 & 1047 & & 1098 & 3671 & & & & \\
\hline & & & & & 3695 & & & & \\
\hline \multirow{5}{*}{ S-5 } & 460 & 467 & 645 & 422 & 3644 & 920 & 1410 & 1457 & 1323 \\
\hline & 696 & 587 & 1142 & 724 & 3671 & 3630 & 1824 & 1555 & 2850 \\
\hline & 778 & & & 990 & & & & 1792 & 2927 \\
\hline & 1090 & & & & & & & & \\
\hline & 1615 & & & & & & & & \\
\hline \multirow{6}{*}{ S-6 } & 458 & 588 & 651 & 408 & 3624 & 872 & 1821 & 1793 & 2854 \\
\hline & 520 & & 1040 & 725 & 3645 & 3400 & & 2512 & 2928 \\
\hline & 693 & & 1138 & & 3666 & & & & 2963 \\
\hline & 777 & & & & & & & & \\
\hline & 1081 & & & & & & & & \\
\hline & 1611 & & & & & & & & \\
\hline
\end{tabular}


are weathered from metamorphic origin [40] [41]. The presence of absorption peaks in between 1611 - 1622 $\mathrm{cm}^{-1}$ is indicative to the origin of the observed silicate minerals [23].

In the mid infrared spectra of alkali felspars in between the range $1200-400 \mathrm{~cm}^{-1}$ are classified as: the bands at $1145 \mathrm{~cm}^{-1}$ and $1110 \mathrm{~cm}^{-1}$ are due to Si-O stretching vibration, band at $1051 \mathrm{~cm}^{-1}$ and $1110 \mathrm{~cm}^{-1}$ are assign to $\mathrm{Al}-\mathrm{O}$ stretching vibration, the bands at $768 \mathrm{~cm}^{-1}$ and $728 \mathrm{~cm}^{-1}$ were assigned to $\mathrm{Si}-\mathrm{Si}$ and $\mathrm{Al}-\mathrm{Si}$ stretching vibration respectively, the bands at $648 \mathrm{~cm}^{-1}$ and $585 \mathrm{~cm}^{-1}$ were assigned to O-Si-O and O-Al-O bending vibrations, bands at $538 \mathrm{~cm}^{-1}$ and $467 \mathrm{~cm}^{-1}$ were assigned to coupling between O-Si-O deformation and K-O stretching vibrations, and the band at $428 \mathrm{~cm}^{-1}$ is assigned to Si-O-Si deformation [39] [42]-[48]. In the Table 4, the peak in the range $586-589 \mathrm{~cm}^{-1}$ arising due to O-Si-(Al)-O bending vibration in the studied samples indicates the presence of microcline. The peak corresponding to the range $532-540 \mathrm{~cm}^{-1}$ is arising due to Si-O asymmetrical bending vibrations and $644-651 \mathrm{~cm}^{-1}$ is arising due to Al-O-coordination vibrations and these peaks are indicative to the presence of orthoclase. The weak or shoulder assigned at $408-422 \mathrm{~cm}^{-1}$ and $721-725 \mathrm{~cm}^{-1}$ is corresponding to Si-O-Si deformation and Al-Si stretching vibration respectively which is indicative to the presence of albite in the observed samples [39] [42]-[48].

In the infrared spectra of the samples (Figure 2 and Table 4) $\mathrm{OH}$ vibrations has been investigated, whose absorption bands appear at different frequencies depending on the cations directly linked to the hydroxyls. This permits the determination of cation distribution around hydroxyls and thus allows assessing short-range cation ordering [36]. The structure of kaolin minerals consist of a sheet of corner-sharing tetrahedra, sharing a plane of oxygens and hydroxyls (inner hydroxyls) with a sheet of edge-sharing octahedral with every third site vacant (dioctahedral). The general features of the $\mathrm{OH}$ stretching absorption bands are well established for kaolin. The band observed at around $3624-3627 \mathrm{~cm}^{-1}$ has been ascribed to the inner hydroxyls, and the bands observed at around the other three characteristic bands are generally ascribed to vibrations of the external hydroxyls. The studied sample exhibits the bands 3695, 3660 - 3671, 3644 - 3646 and 3624 - $3627 \mathrm{~cm}^{-1}$ nearer the characteristic $\mathrm{OH}$ stretching bands at 3696, 3669, 3645 and $3620 \mathrm{~cm}^{-1}$ of kaolinite [36]. The absorption bands observed around $3400 \mathrm{~cm}^{-1}$ could be assigned to the $\mathrm{OH}$ vibrational mode of the hydroxyl molecule, which is observed in almost all the natural hydrous silicates. The observed bands at $1005-1015 \mathrm{~cm}^{-1}$ are close to the SiO deformation band obtained for theoretical kaolinite. The absorption band at $1118 \mathrm{~cm}^{-1}$ is identical to the Si-O normal to the plane stretching found around $1120 \mathrm{~cm}^{-1}$. The observed bands in the range $870-871 \mathrm{~cm}^{-1}$ and $920-926$ $\mathrm{cm}^{-1}$ are assigned to (Al-Mg-OH) deformation and (Al-Al-OH) deformation respectively. The peak at $920 \mathrm{~cm}^{-1}$ is attributed to illite [43] [48]-[50]. All studied samples exhibits weak absorption bands at $2849-2854 \mathrm{~cm}^{-1}$ and $2922-2988 \mathrm{~cm}^{-1}$ arises due to symmetric and asymmetric stretching of $\mathrm{CH}$ group which suggest the presence of organic carbon [51] [52].

The observed bands at $1428-1433 \mathrm{~cm}^{-1}$ is due to $\left(\mathrm{CO}_{3}\right)^{2-}$ stretching mode vibration (Table 4). The other peak at $1410 \mathrm{~cm}^{-1}$ is arises due to doubly degenerate asymmetric stretching mode vibration. These vibrations are generally sensitive to the side symmetry for the carbonate group [43] [53]-[57]. The carbonate structure contains isolated $\mathrm{CO}_{3}^{2-}$ group with a doubly degenerate symmetric stretch (v3) at the region $1508-1555 \mathrm{~cm}^{-1}$ [58] [59]. Another bands at $1792-1793 \mathrm{~cm}^{-1}$ and $1796 \mathrm{~cm}^{-1}$ arises due to $\mathrm{C}=\mathrm{O}$ stretching mode vibration and combinational mode of vibration respectively. Another combinational mode of vibration band is observed at $1821-1825$ $\mathrm{cm}^{-1}$. These bands are indicative of the presence of calcite. The bands at $1455-1459 \mathrm{~cm}^{-1}$ and $2512-2519 \mathrm{~cm}^{-1}$ arises due to $\mathrm{C}-\mathrm{O}$ bending mode vibration and $\mathrm{O}-\mathrm{H}$ stretching mode vibration respectively. These bands are significant to calcite and aragonite group minerals [60].

\section{Conclusion}

The present study indicates the principal constituents of the studied sediments are quartz, feldspar (microcline, orthoclase and albite), carbonates (calcite and aragonite) and clay (kaolinite and illite) minerals. Among the different minerals, quartz, feldspar and kaolinite are most abundant in the samples. Hence, these minerals are considered to be main or major constituents of the samples. The presence of infrared absorption peaks in between 1611 $1622 \mathrm{~cm}^{-1}$ in this study is indicative to the weathered metamorphic origin of the silicate minerals. The elemental correlation is indicative to the metamorphosed pyrophanite $\left(\mathrm{MnTiO}_{3}\right)$ deposition. The negative correlations of $\mathrm{SiO}_{2}$ with major elements is authenticated the presence of bulk quartz grains. The strong negative correlation of $\mathrm{SiO}_{2}$ with $\mathrm{CaO}$ and $\mathrm{Al}_{2} \mathrm{O}_{3}$ is indicative to the primary depositional environment of carbonates and increase in clay fraction respectively. The interrelation between CIA, PIA, Al/Na and K/Na reflects the silicate weathering in- 
tensity. The present study exhibits the studied samples belong to the intermediate silicate weathering.

\section{Acknowledgements}

We thank Directors, National Geophysical Research Institute (NGRI-CSIR), Hyderabad and North East Institute of Science and Technology (NEIST-CSIR), Jorhat for their cooperation during this work. We also thank Dr. J.R. Chetia, Dibrugarh University, Dibrugarh, for his assistance in the FTIR analysis.

\section{References}

[1] Borole, D.V., Sarin, M.M. and Somayajulu, B.L.K. (1982) Indian Journal of Marine Sciences, 11, 51-62.

[2] Subramanian, V. (1987) Journal of the Geological Society of India, 29, 205-220.

[3] Subramanian, V., Grieken, R.V. and Dack, L.V. (1988) Environmental Geology and Water Sciences, 9, 93-103. http://dx.doi.org/10.1007/BF02449940

[4] Subramanian, V., Van’t Dack, L. and Grieken, V. (1985) Chemical Geology, 48, 271-279. http://dx.doi.org/10.1016/0009-2541(85)90052-X

[5] Seralathan, P. (1987) Indian Journal of Marine Sciences, 16, 235-239.

[6] Ramesh, R., Subramanian, V. and Van Grieken, R. (1990) Environmental Geology and Water Sciences, 15, 303-324. http://dx.doi.org/10.1007/BF01706412

[7] Chakrapani, G.J. and Subramanian, V. (1990) Chemical Geology, 70, 247-266.

[8] Singh, M., Ansari, A.A., Muller, G. and Singh, I.B. (1997) Environmental Geology, 29, 246-252. http://dx.doi.org/10.1007/s002540050123

[9] Kotoky, P., Baruah, J., Baruah, N.K. and Sarma, J.N. (1997) Journal of Human Ecology, 6, 55-67.

[10] Singh, A.K. (1999) Journal of the Geological Society of India, 53, 219-231.

[11] Pattan, J.N., Parthiban, G., Prakash Babu, C., Khadge, N.H., Paropkari, A.L. and Kodagali, V.N. (2008) Journal of the Geological Society of India, 71, 107-114.

[12] Dekov, V.M. (1998) Science of the Total Environment, 212, 89-105. http://dx.doi.org/10.1016/S0048-9697(97)00132-0

[13] Braun, J.J., Descloîtres, M., Riotte, J., Fleury, S., Barbiero, L., Boeglin, J., Violette, A., Lacarce, E., Ruiz, L., Sekhar, M., Kumar, M.S.M., Subramanian, S. and Dupré, B. (2009) Geochimica et Cosmochimica Acta, 73, 935-961. http://dx.doi.org/10.1016/j.gca.2008.11.013

[14] Sarin, M.M., Krishnaswami, S., Dilli, K., Somayajulu, B.L.K. and Moore, W.S. (1989) Geochimica et Cosmochimica Acta, 53, 997-1009. http://dx.doi.org/10.1016/0016-7037(89)90205-6

[15] Harris, N., Bickle, M.J., Chapman, H., Fairchild, I. and Bunbury, J. (1998) Chemical Geology, 144, 205-220. http://dx.doi.org/10.1016/S0009-2541(97)00132-0

[16] Galy, A. and France-Lanord, C. (1999) Chemical Geology, 159, 31-60. http://dx.doi.org/10.1016/S0009-2541(99)00033-9

[17] Galy, A. and France-Lanord, C. (2001) Geology, 29, 23-26. http://dx.doi.org/10.1130/0091-7613(2001)029<0023:HERITH>2.0.CO;2

[18] Dalai, T.K., Krishnaswami, S. and Sarin, M.M. (2002) Geochimica et Cosmochimica Acta, 66, 3397-3416. http://dx.doi.org/10.1016/S0016-7037(02)00937-7

[19] Singh, S.K. and France-Lanord, C. (2002) Earth and Planetary Science Letters, 202, 645-662. http://dx.doi.org/10.1016/S0012-821X(02)00822-1

[20] Singh, S., Sarin, M.M. and France-Lanord, C. (2005) Geochimica et Cosmochimica Acta, 69, 3573-3588. http://dx.doi.org/10.1016/j.gca.2005.02.033

[21] Wallmann, K. (2001) Geochimica et Cosmochimica Acta, 65, 3005-3025. http://dx.doi.org/10.1016/S0016-7037(01)00638-X

[22] Saikia, B.J. (2011) Mineralogical Magazine, 73, 1781.

[23] Saikia, B.J., Goswami, S.R. and Borah, R.R. (2014) International Journal of Physical Sciences, 9, 475-486.

[24] Parthasarathy, G. (2002) Journal of Applied Geophysics, 58, 321-329. http://dx.doi.org/10.1016/j.jappgeo.2005.05.008

[25] McLennan, S.M. (1993) The Journal of Geology, 101, 295-303. http://dx.doi.org/10.1086/648222

[26] Feng, R. and Kerrich, R. (1990) Geochimica et Cosmochimica Acta, 54, 1061-1081. http://dx.doi.org/10.1016/0016-7037(90)90439-R 
[27] Nesbitt, H. and Young, G.M. (1982) Nature, 299, 715-717. http://dx.doi.org/10.1038/299715a0

[28] Fedo, C.M., Nesbitt, H.W. and Young, G.M. (1995) Geology, 23, 921-924. http://dx.doi.org/10.1130/0091-7613(1995)023<0921:UTEOPM>2.3.CO;2

[29] Cox, R., Lowe, D.R. and Cullers, R.L. (1995) Geochimica et Cosmochimica Acta, 59, 2919-2940. http://dx.doi.org/10.1016/0016-7037(95)00185-9

[30] Duzgoren-Aydin, N., Aydin, A. and Malpas, J. (2002) Engineering Geology, 63, 99-119. http://dx.doi.org/10.1016/S0013-7952(01)00073-4

[31] Price, J.R. and Velbel, M.A. (2003) Chemical Geology, 202, 397-416. http://dx.doi.org/10.1016/j.chemgeo.2002.11.001

[32] Roy, P.D., Caballeroa, M., Lozanoc, R. and Smykatz-Klossd, W. (2008) Chemie der Erde-Geochemistry, 68, $383-393$. http://dx.doi.org/10.1016/j.chemer.2008.04.001

[33] Gadsden, J.A. (1975) Infrared Spectra of Minerals and Related Inorganic Compounds. Butterworths, London.

[34] Saikia, B.J., Parthasarathy, G. and Sarmah, N.C. (2008) Bulletin of Materials Science, 31, 775-779. http://dx.doi.org/10.1007/s12034-008-0123-0

[35] Saikia, B.J., Parthasarathy, G. and Sarmah, N.C. (2009) The Journal of American Science, 5, 71-78.

[36] Saikia, B.J. and Parthasarathy, G. (2010) Journal of Modern Physics, 1, 206-210. http://dx.doi.org/10.4236/jmp.2010.14031

[37] Saikia, B.J. (2014) Journal of Materials Physics and Chemistry, 2, 28-33. http://dx.doi.org/10.12691/jmpc-2-2-3

[38] Hlavay, J., Jonas, S., Elek, S. and Inczedy, J. (1977) Clays and Clay Minerals, 25, 451-456. http://dx.doi.org/10.1346/CCMN.1977.0250611

[39] Hlavay, J., Jonas, S., Elek, S. and Inczedy, J. (1978) Clays and Clay Minerals, 26, 139-143. http://dx.doi.org/10.1346/CCMN.1978.0260209

[40] Keller, W.D. and Pickett, E.E. (1949) The American Mineralogist, 34, 855-868.

[41] Ramasamy, V., Murugesan, S. and Mullainathan, S. (2004) Bulletin of Pure and Applied Science, 25, 49-55.

[42] White, J.L. (1971) Soil Science, 112, 22-31. http://dx.doi.org/10.1097/00010694-197107000-00005

[43] Farmer, V.C. (1974) The Infrared Spectra of Minerals. Mineralogical Society, London. http://dx.doi.org/10.1180/mono-4

[44] Karr, C. (1975) Infrared and Raman Spectroscopy of Lunar and Terrestrial Minerals. Academic Press, New York, 1-3.

[45] Ghosh, S.N. (1978) Journal of Material Science, 13, 1877-1886. http://dx.doi.org/10.1007/BF00552894

[46] Russell, J.D. (1987) Infrared Methods. In: Wilson, M.J., Ed., A Hand Book of Determinative Methods in Clay Mineralogy, Blackie and Son Ltd., New York.

[47] Neog, A.K., Boruah, R.K., Sahu, O.P., Borah, P.C., Ahmed, W. and Boruah, G.D. (1999) Asian Chemical Letters, 3, 172-175.

[48] Xu, Z., Cornilsen, B.C., Popko, D.C., Penning, W.D., Wood, J.R. and Hwang, J.Y. (2001) International Journal of Vibrational Spectroscopy, 5, 4.

[49] Clark, R.N., King, T.V.V., Kiejwa, M., Swayze, G.A. and Verge, N. (1990) Journal of Geophysics Research, 95, 12653-12680. http://dx.doi.org/10.1029/JB095iB08p12653

[50] Benedetto, G.E.D., Laviano, R., Sabbatini, L. and Zambonin, P.G. (2002) Journal of Cultural Heritage, 3, 177-186. http://dx.doi.org/10.1016/S1296-2074(02)01178-0

[51] Saikia, B.J., Parthasarathy, G. and Sarmah, N.C. (2009) Natute and Science, 7, 45-51.

[52] Saikia, B.J., Parthasarathy, G., Sarmah, N.C. and Baruah, G.D. (2007) Geochimica et Cosmochimica Acta, $71,867$.

[53] Ndukwe, N.A. and Jenmi, F.O. (2008) Pollution Research, 27, 539-543.

[54] Adams, S.J. and Ford, D. (2001) Atmospheric Environment, 35, 4073-4080. http://dx.doi.org/10.1016/S1352-2310(01)00215-1

[55] Beaman, A. and Kingsbury, R. (1984) Clean Air, 14, 74-81.

[56] Chester, R. and Green, R.N. (1968) Chemical Geology, 3, 199-212. http://dx.doi.org/10.1016/0009-2541(68)90020-X

[57] Chester, R. and Elderfield, H. (1967) Sedimentology, 9, 5-21. http://dx.doi.org/10.1111/j.1365-3091.1967.tb01903.x

[58] Saikia, B.J., Parthasarathy, G., Sarmah, N.C. and Baruah, G.D. (2008) Bulletin of Materials Science, 31, 155-158. http://dx.doi.org/10.1007/s12034-008-0027-z

[59] Saikia, B.J., Parthasarathy, G., Sarmah, N.C. and Baruah, G.D. (2007) Geochimica et Cosmochimica Acta, 71, 866.

[60] Huang, C. K. and Kerr, P.F. (1960) American Mineralogist, 45, 311-324. 